\title{
RISK FACTORS ASSOCIATED WITH TEMPORARY CATHETER-RELATED INFECTION IN PATIENTS ON DIALYSIS TREATMENT
}

\author{
Palmiane de Rezende Ramim Borges ${ }^{1}$, João Bedendo ${ }^{2}$
}

\begin{abstract}
${ }^{1}$ M.Sc. in Nursing. Specialist in Nephrology. Maringá, Paraná, Brazil. E-mail: palmirezende@hotmail.com
2 Ph.D. in Infectious Diseases. Associate Professor, Universidade Estadual de Maringá. Paraná, Brazil. E-mail: jbedendo@yahoo. com.br
\end{abstract}

\begin{abstract}
This study aims to identify risk factors associated with temporary hemodialysis catheter-related infection, in patients on dialysis treatment in a teaching hospital. This is a prospective study performed from November of 2012 to May of 2013, with 129 patients. Sociodemographic, clinical and biochemical data were collected from patient charts. In patients with a catheter,, $48.8 \%$ had catheter-related infection, $65 \%$ were male, $65 \%$ were 60 years of age or older, $85.3 \%$ had the catheter because they were diagnosed with acute renal failure, and $88 \%$ were hospitalized in an intensive care unit. There was a significant correlation between the independent variables and the outcome of infection. The risk factors associated with temporary hemodialysis catheter-related infection were: length of time of catheter use, the change of device, death, and complications during a hemodialysis session.
\end{abstract}

DESCRIPTORS: Risk factors. Catheter-related infections. Renal insufficiency. Renal dialysis.

\section{FATORES DE RISCO ASSOCIADOS À INFECÇÃO DE CATETER PROVISÓRIO EM PACIENTES SOB TRATAMENTO DIALÍTICO}

\begin{abstract}
RESUMO: Este estudo objetivou identificar os fatores de risco associados à infecção de cateter provisório para hemodiálise em pacientes em tratamento dialítico em um hospital escola. Trata-se de um estudo prospectivo, realizado no período de novembro de 2012 a maio de 2013, com 129 pacientes. Os dados sóciodemograficos, clínicos e bioquímicos dos participantes foram coletados dos prontuários. Entre os pacientes que foram submetidos à implantação do cateter, $48,8 \%$ apresentaram infecção relacionada ao cateter, $65 \%$ eram do sexo masculino, $65 \%$ possuíam idade igual ou superior a 60 anos, 85,3\% utilizaram o cateter por terem sido diagnosticados com insuficiência renal aguda e $88 \%$ foram internados em unidade de terapia intensiva. Houve correlação significativa entre as variáveis independentes e o desfecho infecção. Os fatores de risco que se associaram à infecção relacionada à implantação do dispositivo foram: tempo de permanência do cateter, troca do dispositivo, óbito e intercorrências durante a sessão de hemodiálise.
\end{abstract}

DESCRITORES: Fatores de risco. Infecções relacionadas a cateter. Insuficiência renal. Diálise renal.

\section{FACTORES DE RIESGO ASOCIADOS A LA INFECCIÓN DE CATÉTER PROVISORIO EN PACIENTES EN TRATAMIENTO DIALÍTICO}

RESUMEN: Este estudio tuvo como objetivo identificar los factores de riesgo asociados a la infección de catéter provisorio para hemodiálisis en pacientes en tratamiento dialítico en un hospital escuela. Se trata de un estudio prospectivo, realizado en el período entre noviembre de 2012 y mayo de 2013, con 129 pacientes. Fueron colectados: registros sociodemográficos, clínicos y bioquímicos de los participantes se obtuvieron de los registros médicos. Entre los pacientes que fueron sometidos a la implantación del catéter, el $48,8 \%$ presentaron infección relacionada con catéter, el $65 \%$ eran del sexo masculino, el $65 \%$ tenían edad igual a 60 años o más, el 85,3\% utilizaron el catéter porque hubieran sido diagnosticados con insuficiencia renal aguda y el $88 \%$ fueron hospitalizados en la unidad de terapia intensiva. Hubo correlación significativa entre las variables independientes y el resultado infección. Los factores de riesgo asociados a la infección relacionada a la implantación del catéter temporal para hemodiálisis fueron: tiempo de permanencia del catéter, la troca del dispositivo, óbito y complicaciones durante la sesión de hemodiálisis.

DESCRIPTORES: Factores de riesgo. Infecciones relacionadas con cateteres. Insuficiencia renal. Diálisis renal. 


\section{INTRODUCTION}

The number of patients with chronic renal failure (CRF) has increased progressively and alarmingly in our country in recent years, associated with chronic diseases and the aging of the population itself. ${ }^{1}$ This increased number of patients has required technological advances such as the modernization of hemodialysis machines and creation of new biomaterials. Dialysis has therefore become more effective and guarantees a greater quality of life, and life expectancy, to those with renal failure. ${ }^{2}$ Temporary hemodialysis catheters have facilitated emergency access for patients requiring immediate hemodialysis. ${ }^{3}$ In addition, these devices have also been important in controlling morbidity and mortality, optimizing the treatment of patients with acute renal failure (ARF) without an available access for hemodialysis, or those with CRF who have lost their permanent access.

Studies show that vascular access for hemodialysis consist of an arteriovenous fistula (AVF). When there are difficulties obtaining an AVF, the main alternative is the use a of double-lumen catheter (DLC). ${ }^{4}$ Despite being a safe option in emergency situations, unlike the permanent vascular access, temporary venous catheters have a high incidence of complications, such as infection, thrombosis, lower dwell time compared to other vascular accesses, and a lower blood flow rate, which reduces the effectiveness of hemodiaysis..$^{5-6}$

The temporary catheter is primarily responsible for about $48-73 \%$ of bacteremia occurring in patients on hemodialysis treament. ${ }^{7}$ The high incidence of intravenous line-related infections has stimulated the development of studies to determine the specific elements that cause this phenomenon because general factors such as clinical conditions, extremes of age and comorbidities such as diabetes, hypertension, obesity and malnutrition are already known. ${ }^{8}$ Risk factors for infection such as the colonization of the skin around the catheter insertion site and catheter contamination before and during its insertion as a result of lack of aseptic technique, and/or contamination due to manipulation of the catheter during dressing change has been investigated. ${ }^{9}$ Infection related to the environment where the hemodialysis sessions are performed have also been investigated because they occur simultaneously in one place, which facilitates the spread of microorganisms via direct or indirect contact, through devices, equipment, surfaces or hands of the heath care professionals. ${ }^{10}$

Considering the above and in view of the need for further information on the epidemiology of temporary hemodialysis catheter-related infections, we proposed this study to identify risk factors associated with these infections related to device implantation in patients on dialysis in a hospital school .

\section{METHOD}

This is a prospective epidemiological study developed with patients with temporary hemodialysis catheter admitted to a 250-bed teaching hospital in Londrina, northern Paraná. The inclusion criteria were: hospitalized patients submitted to implantation of a temporary polyurethane catheter, 18 years old or over, of both genders, with acute or chronic renal failure, between November 2012 and May 2013. Patients who had the hemodialysis changed, those who abandoned treatment or were discharged soon after implantation of the catheter and made follow-up impossible were excluded.

Data were collected from patients' charts by means of an instrument based on previous studies, ${ }^{3,11-12}$ with gender, age, ARF or CRF, inpatient unit, used access site, catheter dwell time, reason for catheter change, reason for catheter removal, complications, laboratory test results.

After filling out the data collection instrument, infection was defined as the outcome variable. The variables gender, age, acute or chronic renal failure, inpatient unit, site access used, catheter dwell time, reason for catheter change, reason for catheter removal and infectious complications were defined as independent variables. The records were entered and processed in the Statistical Package for Social Sciences (SPSS) version 15.0. It was an intentional sample. Descriptive statistics was performed using frequencies, means and percentages. Data normality was evaluated through the Kolmogorov-Smirnov test. The Student's t test was used to determine whether there were differences in age and catheter dwell time between groups with or without infection. A $\mathrm{p}<0.05$ was considered statistically significant, with a $95 \%$ confidence interval. A logistic regression followed by the odds ratio test were used to assess the association between the outcome variable and the independent variables. The study was authorized by the Hospital Director Board, the Institutional 
Research Committee, and the Permanent Committee on Ethics in Research with human beings, protocol n.160.441/12 at the Universidade Estadual de Maringa, in line with Resolution no. 466/12 of the National Health Council, which establishes guidelines for research with human subjects.

\section{RESULTS}

During the study period, 129 patients were followed: $48.8 \%$ had a hemodialysis temporary catheter-related infection, $65 \%$ were male, $85.3 \%$ used the catheter due to a ARF diagnosis and 88\% were in an intensive care unit (ICU).

Table 1 shows the characteristics of patients submitted to insertion of a hemodialysis temporary catheter, according to study variables and the occurrence of infection. It presents the risk factors associated with catheter infection according to the clinical and epidemiological variables of the study, which showed a statistical significance.

Table 1 - Distribution of patients submitted to hemodialysis temporary catheter insertion, according to the study variables and the occurrence of infection. Londrina-Paraná, Brazil, 2013

\begin{tabular}{|c|c|c|c|c|}
\hline \multirow[t]{2}{*}{ Variable } & \multicolumn{2}{|c|}{ Infection $(n=129)$} & \multirow[t]{2}{*}{$\mathbf{p}$} & \multirow[t]{2}{*}{ Odds Ratio } \\
\hline & Yes & No & & \\
\hline Gender & & & 0.993 & $1.003(0.486-2.070)$ \\
\hline Female & $22(17.05)$ & $23(17.83)$ & & \\
\hline Male & $41(31.79)$ & $43(33.33)$ & & \\
\hline Age Group & & & 0.718 & $1.143(0.553-2.360)$ \\
\hline$<60$ years & $42(32.56)$ & $42(32.56)$ & & \\
\hline$\geq 60$ years & $21(16.28)$ & $24(18.60)$ & & \\
\hline Catheter dwell time & & & 0.001 & $2.634((1.690-4.105)$ \\
\hline$<9$ days & $20(15.5)$ & $50(71.4)$ & & \\
\hline$\geq 9$ days & $43(33.33)$ & & & \\
\hline \multicolumn{5}{|l|}{ Insertion site } \\
\hline Subclavian & $10(7.75)$ & $11(8.53)$ & 0.456 & $1.877(0.355-3.784)$ \\
\hline Jugular & $10(7.75)$ & $16(12.40)$ & 0.322 & $1.658(0.541-2.337)$ \\
\hline Femoral & $43(33.33)$ & $39(30.23)$ & & 1 \\
\hline Reason for catheter insertion & & & 0.103 & $2.330(0.826-6.574)$ \\
\hline Acute kidney disease & $57(44.19)$ & $53(41.09)$ & & \\
\hline Chronic kidney disease & $6(4.65)$ & 13(10.08) & & \\
\hline Inpatient unit & & & 0.189 & $0.389(0.108-1.404)$ \\
\hline Ward & $3(2.33)$ & $27(20.93)$ & & \\
\hline Intensive care unit & $60(46.51)$ & $39(30.23)$ & & \\
\hline
\end{tabular}

The Student's t test showed a significant correlation between infection and catheter dwell time $(p=0.001)$, a mean of nine days of catheter dwell time in patients who developed an infection.

After applying the logistic regression test, followed by the odds ratio test, there was a statistically significant association between the reason for catheter change and infection, with a 10 -fold greater chance of changing occurring due to infection than for any other reason. A great part of the reasons for catheter removal was death $(54.17 \%)$. There was a correlation of the outcome death with infection.

During the hemodialysis sessions, $15.5 \%$ of complications occurred in patients with catheterrelated infections, fever occurring in $84 \%$, followed by bacteremia. A statistical significance was found between infection and complications, the chance of any complications occurring due to infection being five-fold greater than for other reasons $(p=0.001)$.

Table 2 shows the risk factors associated with catheter infection according with the clinical and epidemiological study variables, which showed a statistical significance. 
Table 2 - Factors associated with hemodialysis temporary catheter-infection, according to the clinical and epidemiological variables. Londrina, Paraná, Brazil, 2013

\begin{tabular}{|c|c|c|c|c|}
\hline \multirow{2}{*}{ Variable } & \multicolumn{2}{|c|}{ Infection } & \multirow{2}{*}{$\mathbf{p}$} & \multirow{2}{*}{ Odds Ratio } \\
\hline & Yes & No & & \\
\hline Reason for catheter change & & & 0.04 & $10.214(1.749-59.651)$ \\
\hline Infection & $11(33.3)$ & $2(6.1)$ & & \\
\hline Other & $7(21.2)$ & $13(39.4)$ & & \\
\hline Reason for catheter removal & & & 0.03 & \\
\hline Loss & $2(2.1)$ & $3(3.1)$ & & \\
\hline Infection & $9(9.4)$ & $3(3.1)$ & & \\
\hline Fistula maturation & - & $4(4.2)$ & & \\
\hline Reverted acute renal failure & $4(4.2)$ & $17(17.7)$ & & \\
\hline Death & $30(31.3)$ & 22(22.9) & & \\
\hline CAPD $^{*}$ start & - & $2(2.1)$ & & \\
\hline Complications & & & 0.001 & $5.674(1.976-16.294)$ \\
\hline Yes & $20(15.5)$ & $05(3.9)$ & & \\
\hline No & $43(33.3)$ & $61(47.3)$ & & \\
\hline
\end{tabular}

The Student's $t$ test was used to assess the relationship between infection and age. There was no statistically significant correlation, since the mean age in the whole group submitted to catheter insertion was 61 years old, but only $33.3 \%$ of the sample with infection was older than 60 years.
As to the site of catheter insertion (Table 3 ), infection was more prevalent in the femoral region. However, after statistical analysis, there was no correlation between the catheter insertion site and the frequency of infection.

Table 3 - Profile of the catheter insertion according to location, dwell time and prevalence of infection. Londrina, Paraná, Brazil, 2013

\begin{tabular}{lccc}
\hline Catheter insertion site (\%) & Mean catheter dwell time (days) & Infection prevalence (\%) \\
\hline Subclavian & 20.2 & 9.62 & 15.9 \\
Jugular & 16.3 & 8.73 & 15.9 \\
Femoral & $63.5^{*}$ & 9.30 & $68.3^{\dagger}$ \\
\hline
\end{tabular}

* Significant difference $(\mathrm{p}<0.05)$ compared to other insertion sites; $\uparrow$ Significant difference $(\mathrm{p}<0.05)$ regarding the prevalence of infection.

After the odds ratio test, there was no statistical significance between gender and inpatient unit, the occurrence of infection being independent of gender and inpatient sector.

\section{DISCUSSION}

In the past, the infection rate was an exclusive concern of hospital infection control committees (HICC), which, in most cases, instituted prevention and control programs. ${ }^{13}$ Currently, this indicator is useful not only for directing the HICC actions, but also because it represents a major indicator of quality of care in the health care services. ${ }^{14}$

The patient severity and the greater frequency of invasive procedures are part of the factors that make hospital infection an important variable in the ICU. From the ICUs, microorganisms can spread to other units, either due to patient transfer or staff change. ${ }^{15}$ In this study, most of the infected patients were male and were hospitalized in the ICU, characteristics that are similar to the results of other studies. ${ }^{16-17}$

The superiority of the hemodialysis temporary catheter insertion due to ARF was about five-fold higher compared with CRF, which was also observed in other studies. ${ }^{18-19}$ This is possibly caused by the delay in the referral of these patients to the nephrologist, with a need for emergency hemodialysis and cases of ARF that is secondary to other diseases.

The high incidence of ARF and its complications and the multiple invasive procedures 
imply the need to hospitalize patients in the ICUs, predisposing them to greater risks of infection, mainly by multirresistent microorganisms. ${ }^{20}$ The results showed that most patients were in the ICU. Another study also found that patients in the ICU when compared to the other units are five to ten-fold more likely to acquire health care-related infections. ${ }^{21}$ In this study, the statistical analysis did not show a significant association between infection and inpatient units.

Regarding the catheter dwell time, the literature recommends a temporary use for a maximum of three weeks, ${ }^{22}$ due to the high infection rates in patients with ARF. ${ }^{23}$ Moreover, prolonged use of central venous catheters increases the risk of current blood infections. ${ }^{24-25}$ The results showed a statistically significant relationship between the catheter dwell time with the presence of infection.

Even after the multivariate logistic regression, the association between mortality and development of infection is not common sense in the literature. ${ }^{26}$ This study found a high rate of deaths of patients with the temporary catheter, but the use of the device was not declared as causa mortis on death certificates. Therefore, the deaths were not specifically related to the catheter insertion.

The complications during the hemodialysis sessions were relevant when related to infection, fever being the most prevalent, followed by bacteremia. The literature reports that patients using temporary catheters have about 4 to $18 \%$ of bacteremia rates comprising eight thousand average annual cases of sepsis and other device-related infections. ${ }^{27}$

As for insertion site, the jugular, subclavian and femoral veins were used. The literature describes the jugular vein is the favorite access. It is also a way to prevent stenosis of the subclavian vein and enable the subsequent production of the arteriovenous fistula. ${ }^{28}$ Another author, however, states that catheters inserted in the jugular vein when compared to the subclavian vein, caused a $56 \%$ greater chance of a catheter-related infection. ${ }^{12}$ These results differ from our findings, which showed that the most frequently used site was the femoral region, and that there was no statistically significant relationship between infection and the insertion site of the device. The fact should also be considered that most of the patients were in the ICU using central venous catheters for drug therapy, previously inserted into the jugular and subclavian region, and the femoral region is preferred by medical residents, because it is a faster and easier region to insert the catheter.

\section{CONCLUSION}

There was a correlation between some independent variables and the outcome infection, but several other factors can contribute to the development of infection, mainly because most of the studied patients were admitted to the ICU in a severe condition and several other comorbidities.

It was found in this study that the variables catheter dwell time, reason for catheter change and complications during the hemodialysis session were the risk factors associated with infection related to the insertion of a hemodialysis temporary catheter. The identification and control of these risk factors are essential in preventing infection in patients with temporary catheter and should be included in the teaching content by means of technical training of health care professionals and the consequent contribution to the decrease in hospitalization rates and mortality due to complications from procedures related to the temporary catheter.

\section{REFERENCES}

1. Silva NK, Sartori DL, Zink V, Aguiar RB, Schirmer J. A vivência de pacientes que necessitam de transplante renal na espera por um órgão compatível. Texto Contexto Enferm [online]. 2013 Dez [citado 2014 Mar 24]; 22(4):1160-8. Disponível em: http://www.scielo.br/scielo.php?script=sci arttext\&pid=S0104-07072013000400035\& lng=pt

2. Riella MC. Princípios de nefrologia e distúrbios hidroeletrolíticos. Rio de Janeiro (RJ): Guanabara Koogan; 2010.

3. Bonfante GM, Gomes IC, Andrade EI, Lima EM, Acurcio FA, Cherchiglia ML. Duração do uso de cateter temporário para hemodiálise: uma avaliação observacional, prospectivo de unidades renais no Brasil. BMC Nephrol. 2011; 12:63.

4. Nicole AG, Tronchin DMR. Indicadores para avaliação do acesso vascular de usuários em hemodiálise. Rev Esc Enferm USP 2011; 45(1):206-14.

5. Silva GM, Gomes IC, Andrade EIG, Lima EM, Acurcio FA, Cherchiglia ML. Permanent vascular access in patients with end-stage renal disease, Brazil. Rev Saúde Pública. 2011; 45(2):241-8.

6. WadełekJ. Haemodialysis catheters. Anaesthesiology Intensive Therapy. 2010; 62(4):213-7.

7. Ferreira V, Andrade D. Cateter para hemodiálise: retrato de uma realidade. Medicina. 2007; 40(4):582-8.

8. Lima ME, Andrade D, Haas VJ. Avaliação prospectiva da ocorrência de infecção em pacientes críticos de unidade de terapia intensiva. Rev Bras Ter Intens. 2007; 19(3):342-7.

9. Grothe C, Belasco A, Bitencourt A, Vianna L, Sesso R, Barbosa D. Incidence of bloodstream infection among 
patients on hemodialysis by central venous catheter. Rev latino-Am Enfermagem. 2010; 18(1):73-80.

10. Fram DS, Taminato M, Ferreira D, Neves L, Belasco AGS, Barbosa DA. Prevenção de infecção de corrente sanguínea relacionadas a cateter em pacientes em hemodiálise. Acta Paul Enferm. 2009; 22(Esp):564-8.

11. Oliveira AC, Paula AO, Iquiapaza RA, Lacerda ACS. Infecções relacionadas à assistência em saúde e gravidade clínica em uma unidade de terapia intensiva. Rev Gaúcha Enferm. 2012; 33(3):89-96.

12. Trelha TG, Oshiro E, Luzio YC, Paniago AMM, Pontes ERJC, Chang MR. Infecção da corrente sanguínea em pacientes com doença renal em estágio terminal em um hospital de ensino no Brasil centro-oeste. Rev Soc Bras Med Trop. 2013; 46(4):426-32.

13. Fontana RT, Lautert L. Aspectos ético-legais do controle da infecção hospitalar: algumas reflexões relativas ao enfermeiro. Cienc Cuid Saúde. 2008; 7(4):546-50

14. Silva CS, Gabriel CS, Bernardes A, Évora YDM. Opinião do enfermeiro sobre indicadores que avaliam a qualidade na assistência de enfermagem. Rev Gaúcha Enferm. 2009; 30(2):263-71.

15. Leiser JJ; Tognim MCB, Bedendo J. Infecções hospitalares em um centro de terapia intensiva de um hospital de ensino no Norte do Paraná. Cienc Cuid Saúde. 2007; 6(2):181-6.

16. Sesso RC, Lopes AA, Thomé FS, Lugon JR, Santos DR. Relatório do censo brasileiro de diálise de 2010. J Bras Nefrol. 2011; 33(4):442-7.

17. Bernardina LD, Diccini S, Belasco AGS, Bittencourt ARS, Barbosa DA. Evolução clínica de pacientes com insuficiência renal aguda em unidade de terapia intensiva. Acta Paul Enferm. 2008; 21(Esp):174-8.

18. Souza RA, Oliveira EA, Silva JM, Lima EM. Avaliação do acesso vascular parágrafo hemodiálise los criancas e Adolescentes: um estudo de coorte retrospectivo de 10 Anos. J Bras Nefrol. 2011; 33(4):422-30.

19. Ethier J, Mendelssohn DC, Elder SJ, Hasegawa $\mathrm{T}$, Akizawa T, Akiba $\mathrm{T}$ et al. Vascular access use and outcomes: an international perspective from the dialysis outcomes and practice patterns study. Nephrol Dial Transplant. 2008 Oct; 23(10):3219-26.

20. Oliveira AC, Silva RS, Diaz MEP, Iquiapaza RA. Bacterial resistance and mortality in an Intensive Care Unit. Rev Latino-Am Enfermagem [online] 2010 [citado 2011 jun 15]; 18(6):1152-60. Disponível em: http://www.scielo.br/scielo.php?script=sci_ arttext\&pid=S0104-11692010000600016\&lng=en

21. Markogiannakis H, Pachylaki N, Samara E, Kalderi M, Minettou M, Toutouza M, et al. Infections in a surgical intensive care unit of a university hospital in Greece. Int J Infect Agents. 2009; 13(2):145-53.

22. Agência Nacional de Vigilância Sanitária (BR). Regulamento técnico para o funcionamento dos Serviços de Diálise - Resolução-RDC n. 154, de 15 de junho de 2004. Brasília(DF): Anvisa; 2004.

23. Oliveira FC, Alves MDS, Bezerra AP. Co-morbidades e mortalidade de pacientes com doença renal: atendimento terceirizado de nefrologia. Acta Paul Enferm. 2009; 22(Esp):476-80.

24. Bicudo D, Batista R, Furtado GH, Sola A, Medeiros EAS. Risk factors for catheter-related bloodstream infection: a prospective multicenter study in Brazilian intensive care units. Braz J Infect Dis. 2011; 15(4):328-31.

25. Qureshi AL, Abid K. Frequência de infecções relacionadas ao cateter em pacientes hemodialisados urémico. J Pak Med Assoc. 2010; 60:671-5.

26. Beyersmann J, Gastmeier P, Grundmann H, Bärwolff S, Geffers C, Behnke M, et al. Transmissionassociated nosocomial infections: prolongations of intensive care unit stay and risk factor analysis using multistate models. Am J Infect Control. 2008; 36(2):98-103.

27. Ribeiro RCHM. Levantamento sobre a infecção na inserção do cateter de duplo lúmen. Acta Paul Enferm. 2008; 21(Esp):212-5.

28. Vanholder R, Canaud B, Fleck R, Jadoul M, Labriola L, Marti-Monros A. et al. Diagnosis, prevention and treatment of haemodialysis catheter-related bloodstream infections (CRBSI): a position statement of European Renal Best Practice (ERBP). Nephrol Dial Trans Plus. 2010; 3:234-46. 